\title{
EVOLUTIONARY STRATEGIES IN LIZARD REPRODUCTION
}

\author{
Donald W. Tinkle, Henry M. Wilbur, and Stephen G. Tulley \\ Museum and Department of Zoology, University of Michigan, Ann Arbor 48104
}

Received May 19, 1969

Several investigators have dealt in a theoretical way with the evolution of reproductive rates and attendant life history phenomena (Cole, 1954; Lack, 1954, 1966, 1968; Murphy, 1968; Svärdson, 1949; Williams, 1966a, 1966b). Tinkle (1969a) has applied evolutionary principles in an attempt to construct a general theory of the evolution of single-broodedness and iteroparity, of viviparity, and of clutch size and clutch number in lizards. Most of the data presented by him were qualitative.

In this paper we pose a series of questions concerning reproductive strategies which have evolved among one group of vertebrates (the lizards), and provide quantitative data to answer them. We further present comparable data from birds, the vertebrate group most thoroughly studied in this respect. Finally, we suggest the weaknesses in studies of reptilian reproduction in the hope of stimulating future workers to collect data that are essential to answer these specific questions.

\section{Nature of the Problem}

Lizards display variability in their reproductive habits. Some are evidently acyclic in reproduction, while others have restricted reproductive seasons. Among the latter group are species that reproduce once during each season and others that reproduce several times. There are also large differences in clutch size. A single egg may be laid (as in the sphaerodactylines) or two as in most other gekkonids; some iguanids produce more than 20 eggs per clutch and may do this several times in a single season. Finally, there are great differences in age at maturity, in the size attained by breeding adults and in the degree of parental care of the eggs.

Different reproductive strategies are followed by different species of lizards. Some lizards are early-maturing, short-lived and highly fecund; some mature later, live for several years as reproductive adults, lay fewer eggs per clutch and lay less often per season. Taxonomically unrelated species may have convergent strategies as would be expected of such highly adaptive traits. Each strategy may be dictated by a particular set of environmental circumstances such that it may be possible to specify the conditions under which one strategy or the other would prevail, as was attempted by Tinkle (1969a).

Our approach is to pose the following questions concerning reproductive strategies, their diversity, their components and selective values.

1) To what extent is clutch size correlated with body size, with age at first breeding, and with the number of clutches produced per season?

2) Do reproductive differences also exist between populations of the same species?

3) Do the reproductive strategies that we identify here differ in tropical versus temperate species, oviparous versus viviparous species, earlymaturing and short-lived species versus late-maturing, longer-lived ones? Do strategies correspond with taxonomic groups?

4) How do the results obtained compare with those from birds?

5) With what factors should future studies of reptilian reproduction be concerned? 


\section{Materials and Methods}

The data for the present paper come from the literature except where noted in the text. For each species, we obtained the following information whenever possible: minimum size at sexual maturity, average size of breeding females, average clutch size, age at first reproduction, mode of reproduction (whether oviparous or viviparous), number of broods per year, and the climate (temperate versus tropical) in the area of the study (Table 1).

Age at first reproduction has been inexactly determined by most investigators. If papers stated that maturity occurs in the next summer following hatching, we used 12 months as the age at first breeding. Where an author stated that 2 to 3 years were required to reach maturity, we chose the higher figure as a necessary simplification. Broods-per-year is almost always unknown; most estimates were minimal ones. Therefore, we chose to state only that a species was single-brooded or multiple-brooded.

Season as used in this paper means reproductive season. A lizard generally hatches during one season and also grows, often to nearly adult size, during the same season. In spite of this, we use the statement "next season after hatching" as meaning approximately 1 year after hatching. A species that matures and reproduces in the next season after hatching or earlier is considered an early-maturing species; one that matures in a still later season is considered a delayed-maturing species.

To define reproductive strategies 37 species with fairly complete data were clustered in a Prim network (Prim, 1957). The reproductive characters used to compute the dissimilarity matrix were: body size at maturity, clutch size, age at maturity, mode of reproduction and number of broods per year. The distribution of each character was standardized to a distribution of mean 0 and standard deviation of 1 so that each character contributed equally to the dissimilarity matrix. The coefficient of dissimilarity was computed as:

$$
d_{i j}=\sum_{i, k}\left(X_{i j}-X_{j k}\right),
$$

where $X_{i k}$ is the character state of the $k$ th character of species $i$ and $X_{j k}$ is the character state of the $k$ th character of species j. The prim network results from an algorithm which progressively links each species to the species with a life history strategy most similar to it. The resulting diagram (Fig. 2) is unidimensional so that only dimensions along the network are meaningful.

In a few instances we may have placed a particular species in the wrong strategy group simply because data for that species were inadequate, but these discrepancies should not have a significant effect on our generalizations. We have also excluded lizards of the family Gekkonidae from consideration because of the nearly constant clutch size in this group.

Data were incomplete for many species, precluding $2 \times 2 \times 2$ factorial analysis of variance to describe the statistical interactions of mode of reproduction (oviparous versus viviparous), broods per year (single versus multiple), and climate (temperate versus tropical), and to ascertain the effects of each of these factors on the form of the multiple regression of clutch size on age and size at maturity. Because of these inadequacies we grouped for comparison all species for which data were available on any two reproductive parameters (Table 2). For example, one such group contained all those species for which mean clutch size and size at maturity were known, and a simple productmoment correlation coefficient was computed between clutch size and size at maturity within the group. This correlation was assumed to be representative of the relationship between these two variables in lizards as a whole. Similarly, correlation coefficients were computed for all combinations of clutch size, body size and age at maturity. Student's " $t$ " tests 
TABLE 1. Demographic and reproductive data on lizards. $\mathrm{s}=$ single-brooded, $\mathrm{m}=$ multiplebrooded; $\mathrm{o}=$ oviparous, $\mathrm{v}=$ viviparous; $\mathrm{tr}=$ tropical, $\mathrm{tm}=$ temperate.

\begin{tabular}{|c|c|c|c|c|c|c|c|c|c|c|}
\hline & Species & 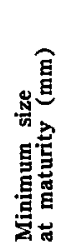 & 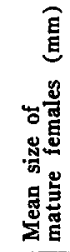 & 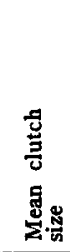 & 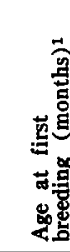 & (8) & 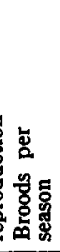 & 苋 & $\begin{array}{c}\text { Study } \\
\text { locality }\end{array}$ & Author(s) \\
\hline & IGUANMAE & & & & & & & & & \\
\hline 1) & $\begin{array}{l}\text { Amblyrhynchus } \\
\text { cristatus } \\
\text { Anolis }\end{array}$ & 一 & 一 & 2.0 & late & $\mathbf{o}$ & $\mathbf{s}$ & $\operatorname{tr}$ & Galapagos & Carpenter (1966) \\
\hline & carolinensis & 45 & 50 & 1.3 & 12 & 0 & $\mathbf{m}$ & tm & Louisiana & $\begin{array}{l}\text { Gordon (1956); } \\
\text { Hamlett (1952) }\end{array}$ \\
\hline 3) & $\begin{array}{l}\text { Anolis } \\
\text { limifrons } \\
\text { Basiliscus }\end{array}$ & 38 & 44 & 1.0 & 8 & 0 & $\mathbf{m}$ & tr & Panama & Sexton et al. (1963) \\
\hline 5) & $\begin{array}{l}\text { vittatus } \\
\text { Corythophanes }\end{array}$ & 83 & - & 4.2 & 12 & o & - & tr & Costa Rica & Hirth (1963) \\
\hline 6) & $\begin{array}{l}\text { percarinatus } \\
\text { Crotaphytus }\end{array}$ & 一 & 一 & 7.1 & 24 & $\mathbf{v}$ & $\mathbf{s}$ & $\operatorname{tr}$ & Guatemala & McCoy (1968) \\
\hline & $\begin{array}{l}\text { collaris } \\
\text { Crotaphytus }\end{array}$ & 92 & - & 7.6 & 12 & $\mathbf{o}$ & $\mathbf{m}$ & $\mathrm{tm}$ & Kansas & Fitch (1956) \\
\hline 8) & $\begin{array}{c}\text { wislizeni } \\
\text { Crotaphytus }\end{array}$ & 87 & - & 3.0 & 24 & $\mathbf{o}$ & - & tm & California & Montanucci $(1965,1967)$ \\
\hline 9) & $\begin{array}{c}\text { wislizeni } \\
\text { Holbrookia }\end{array}$ & 90 & - & 7.3 & 24 & o & s & $\operatorname{tm}$ & Colorado & McCoy (1967) \\
\hline 10) & $\begin{array}{r}\text { maculata } \\
\text { Holbrookia }\end{array}$ & 45 & 54 & 6.1 & 12 & $\mathbf{o}$ & $\mathbf{m}$ & $\operatorname{tm}$ & Texas & Tinkle and Walker (unpub.) \\
\hline 11) & $\begin{array}{c}\text { texana } \\
\text { Holbrookia }\end{array}$ & 55 & 一 & 5.3 & 12 & $\mathbf{o}$ & - & tm & Texas & Cagle (1950) \\
\hline 12) & $\begin{array}{l}\text { texana } \\
\text { Iguana }\end{array}$ & 50 & - & 5.0 & 12 & o & m & tm & Texas & Johnson (1960) \\
\hline 13) & $\begin{array}{c}\text { iguana } \\
\text { Liolaemus }\end{array}$ & - & 一 & 35.0 & late & $\mathbf{o}$ & $\mathbf{s}$ & $\operatorname{tr}$ & Panama & Rand (1968) \\
\hline 14) & $\begin{array}{l}\text { multiformis } \\
\text { Phrynosoma }\end{array}$ & 70 & 81 & 5.8 & 18 & $\mathbf{v}$ & $\mathbf{s}$ & $\mathrm{tm}$ & Peru & Pearson (1954) \\
\hline 15) & $\begin{array}{l}\text { cornutum } \\
\text { Sauromalus }\end{array}$ & - & 60 & 32.0 & - & o & - & tm & Kansas & Givler (1922) \\
\hline & $\begin{array}{c}\text { obesus } \\
\text { Sceloporus }\end{array}$ & - & 一 & - & late & o & s & tm & California & Johnson (1965) \\
\hline 17) & $\begin{array}{l}\text { cyanogenys } \\
\text { Sceloporus }\end{array}$ & 88 & 106 & 13.0 & late & $\mathbf{v}$ & $\mathbf{s}$ & $\mathrm{tm}$ & Texas & Hunsaker (1959) \\
\hline & graciosus & 50 & - & 3.3 & 48 & o & $\mathbf{s}$ & tm & California & $\begin{array}{l}\text { Stebbins (1944, 1948); } \\
\text { Stebbins and Robinson (1946) }\end{array}$ \\
\hline 19) & $\begin{array}{l}\text { Sceloporus } \\
\text { jarrovi } \\
\text { Sceloporus }\end{array}$ & - & 79 & 10.0 & - & $\mathbf{v}$ & s & $\mathrm{tm}$ & Arizona & Carpenter (1960a) \\
\hline 20) & $\begin{array}{l}\text { merriami } \\
\text { Sceloporus }\end{array}$ & 45 & 49 & 3.7 & early & $\mathbf{0}$ & - & $\operatorname{tm}$ & Texas & Chaney and Gordon (1954) \\
\hline & $\begin{array}{l}\text { occidentalis } \\
\text { Sceloporus }\end{array}$ & 62 & - & 8.0 & 24 & $\mathbf{0}$ & - & $\operatorname{tm}$ & California & Davis (1967) \\
\hline & occidentalis & 65 & - & 13.7 & 24 & $\mathbf{o}$ & s & $\operatorname{tm}$ & $\begin{array}{l}\text { Oregon and } \\
\text { California }\end{array}$ & Fitch (1940) \\
\hline
\end{tabular}

\footnotetext{
${ }^{1}$ Early or late designate species for which we could state with fair assurance that a species matured
} in one year (early) or required 2 or more years to mature (late). 
Tabie 1. (Continued)

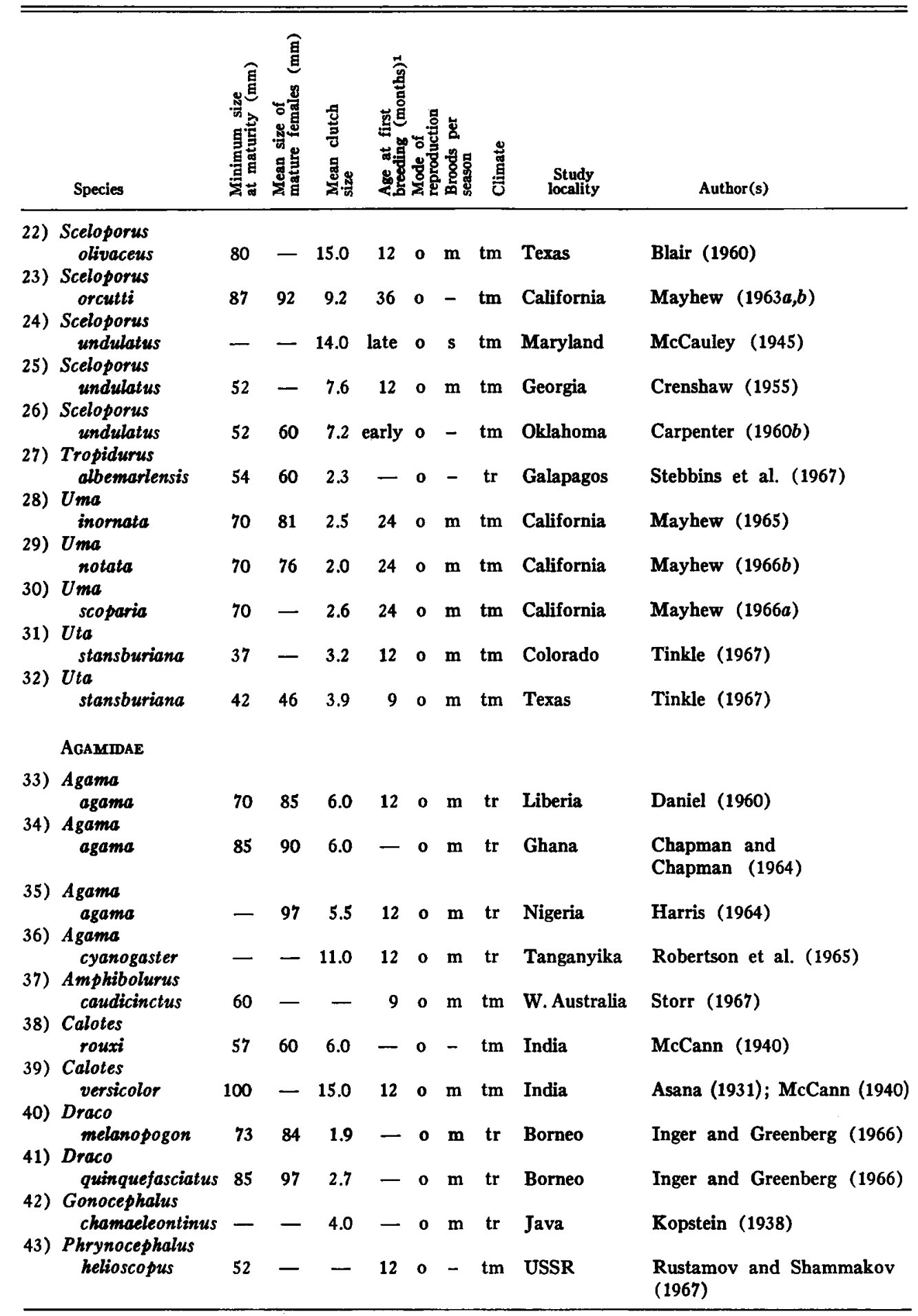


Table 1. (Continued)

\begin{tabular}{|c|c|c|c|c|c|c|c|c|c|c|}
\hline & Species & 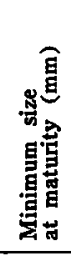 & 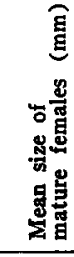 & 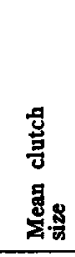 & 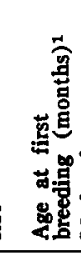 & & 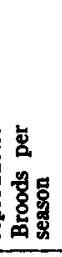 & 苋 & $\begin{array}{c}\text { Study } \\
\text { locality }\end{array}$ & Author(s) \\
\hline \multirow[b]{2}{*}{ 44) } & ANGUIDAE & & & & & & & & & \\
\hline & $\begin{array}{l}\text { Anguis } \\
\text { fragilis } \\
\text { Diploglossus }\end{array}$ & 120 & - & 9.0 & 36 & $\mathbf{v}$ & $\mathbf{s}$ & tm & Europe & Smith (1951) \\
\hline 46) & $\begin{array}{c}\text { costatus } \\
\text { Diploglossus }\end{array}$ & 75 & 85 & 5.6 & - & $\mathbf{v}$ & - & $\operatorname{tr}$ & Hispaniola & Greer (1967) \\
\hline 47) & $\begin{array}{c}\text { crusculus } \\
\text { Gerrhonotus }\end{array}$ & 56 & 62 & 3.4 & - & $\mathbf{v}$ & - & $\operatorname{tr}$ & Jamaica & Greer (1967) \\
\hline 48) & $\begin{array}{c}\text { coeruleus } \\
\text { Gerrhonotus }\end{array}$ & 80 & 100 & 6.2 & late & $v$ & $\mathbf{s}$ & $\mathrm{tm}$ & California & Fitch (1935) \\
\hline & multicarinatus & 112 & - & 11.6 & late & 0 & $\mathbf{s}$ & $\mathrm{tm}$ & California & Fitch (1935) \\
\hline & LACERTIDAE & & & & & & & & & \\
\hline $\begin{array}{l}\text { 49) } \\
\text { 50) }\end{array}$ & $\begin{array}{l}\text { Lacerta } \\
\text { agilis } \\
\text { Lacerta }\end{array}$ & 55 & - & 9.5 & 24 & $\mathbf{0}$ & $\mathbf{s}$ & $\operatorname{tm}$ & England & Smith (1951) \\
\hline & vivipara & - & - & 6.5 & 36 & $\mathbf{v}$ & $\mathbf{s}$ & $\operatorname{tm}$ & Europe & $\begin{array}{l}\text { Rollinat (1934); } \\
\text { Smith (1951) }\end{array}$ \\
\hline 51) & $\begin{array}{l}\text { Takydromus } \\
\text { tachydromoides }\end{array}$ & 40 & 53 & 3.6 & 12 & o & $\mathbf{m}$ & $\operatorname{tm}$ & Japan & $\begin{array}{l}\text { Ishihara (1964); } \\
\text { Fukada (1965) }\end{array}$ \\
\hline 52) & $\begin{array}{l}\text { Takydromus } \\
\text { tachydromoides }\end{array}$ & 43 & - & 3.0 & 12 & $\mathbf{o}$ & $\mathbf{m}$ & $\operatorname{tm}$ & Japan & Telford (1969) \\
\hline & TeidDar & & & & & & & & & \\
\hline $\begin{array}{l}\text { 53) } \\
\text { 54) }\end{array}$ & $\begin{array}{l}\text { Ameiva } \\
\text { festiva } \\
\text { Ameiva }\end{array}$ & 77 & - & 2.4 & 12 & o & $\mathbf{m}$ & $\operatorname{tr}$ & Costa Rica & Smith (1968) \\
\hline 55) & $\begin{array}{l}\text { quadrilineata } \\
\text { Ameiva }\end{array}$ & 64 & - & 2.1 & 12 & 0 & $\mathbf{m}$ & $\operatorname{tr}$ & Costa Rica & Smith (1968) \\
\hline 56) & $\begin{array}{r}\text { quadrilineata } \\
\text { Cnemidophorus }\end{array}$ & 48 & - & 2.0 & 12 & 0 & $\mathbf{m}$ & $\operatorname{tr}$ & Costa Rica & Hirth (1963) \\
\hline 57) & & 60 & 75 & 2.7 & early & 0 & $\mathbf{s}$ & $\mathrm{tm}$ & New Mexico & Medica (1967) \\
\hline 58) & $\begin{array}{c}\text { hyperythrus } \\
\text { Cnemidophorus }\end{array}$ & 53 & 60 & 2.3 & 12 & o & m & $\mathrm{tm}$ & Baja Calif. & Bostic (1966) \\
\hline 59) & $\begin{array}{c}\text { inornatus } \\
\text { Cnemidophorus }\end{array}$ & 50 & 57 & 2.2 & early & 0 & $\mathbf{m}$ & $\mathrm{tm}$ & New Mexico & Medica (1967) \\
\hline 60) & $\begin{array}{r}\text { neomexicanus } \\
\text { Cnemidophorus }\end{array}$ & 60 & 65 & 1.6 & early & 0 & m & $\mathrm{tm}$ & New Mexico & Medica (1967) \\
\hline 61) & $\begin{array}{l}\text { sexlineatus } \\
\text { Cnemidophorus }\end{array}$ & 54 & 61 & 2.3 & 12 & 0 & m & $\mathrm{tm}$ & Kansas & Fitch $(1958,1967)$ \\
\hline 62) & $\begin{array}{l}\text { sexlineatus } \\
\text { Cnemidophorus }\end{array}$ & 55 & 65 & 2.5 & 12 & $\mathbf{o}$ & - & tm & Oklahoma & Carpenter $(1959,1960 b)$ \\
\hline 63) & $\begin{array}{l}\text { sexlineatus } \\
\text { Cnemidophorus }\end{array}$ & 53 & - & 3.1 & early & 0 & - & tm & Texas & Hoddenbach (1966) \\
\hline & $\begin{array}{l}\text { tigris } \\
\text { Cnemidophorus }\end{array}$ & 70 & - & 2.2 & 12 & $\mathbf{o}$ & m & tm & Texas & Hoddenbach (unpubl.) \\
\hline & tigris & 61 & 72 & 2.0 & 12 & 0 & $\mathrm{~m}$ & tm & New Mexico & Medica (1967) \\
\hline
\end{tabular}


Table 1. (Continued)

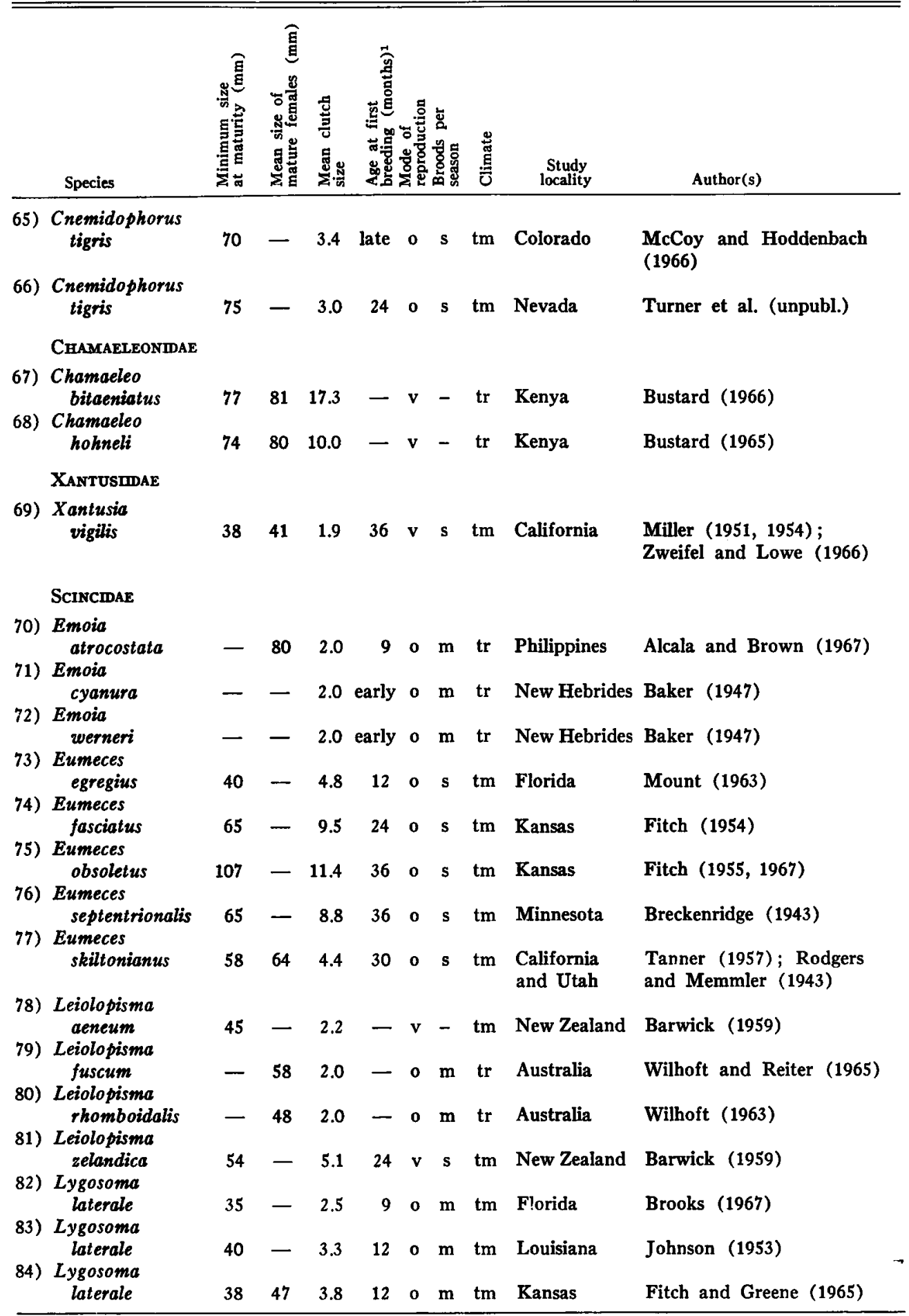


Table 1. (Continued)

\begin{tabular}{|c|c|c|c|c|c|c|c|c|c|}
\hline & Species & 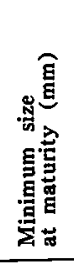 & 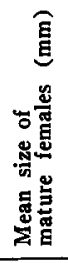 & 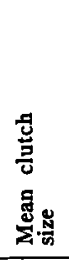 & 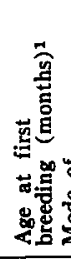 & 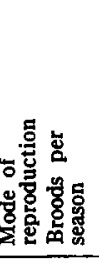 & 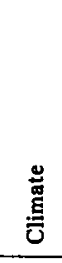 & $\begin{array}{c}\text { Study } \\
\text { locality }\end{array}$ & Author(s) \\
\hline 85) & $\begin{array}{l}\text { Mabuya } \\
\text { multifasciata }\end{array}$ & - & - & 6.0 & 一 & $\mathbf{v} \mathbf{m}$ & tr & Java & Kopstein (1938) \\
\hline 86) & $\begin{array}{r}\text { Mabuya } \\
\text { striata }\end{array}$ & 62 & 70 & 7.0 & 12 & $\mathbf{v}-$ & $\operatorname{tr}$ & Tanganyika & Robertson et al. (1965) \\
\hline 87) & $\begin{array}{l}\text { Neoseps } \\
\quad \text { reynoldsi }\end{array}$ & 45 & - & 2.0 & 12 & o - & $\mathrm{tm}$ & Florida & Telford (1959) \\
\hline 88) & $\begin{array}{l}\text { Sphenomorphus } \\
\text { tanneri }\end{array}$ & 41 & 45 & 2.0 & - & o m & $\operatorname{tr}$ & S.E. Asia & Greer and Parker (1967) \\
\hline
\end{tabular}

of the differences of the means were computed for clutch size, body size and age at maturity between oviparous and viviparous, single-brooded and multiplebrooded, and temperate and tropical species. A Chi Square test of independence was used to test the degree of association between the mode of reproduction and the climate. Because of small sample sizes in the other comparisons, Fisher's Exact Probability Tests were used instead of Chi Square.

There were sufficient data to compute multiple regressions of clutch size on body size and age within single and multiplebrooded, oviparous, tropical and temperate lizards. For comparison with these subsamples, the same analysis was performed for all lizards for which there were data on clutch size and on age and size at maturity. The $F$-ratios of the regression mean squares to the error mean squares were used to test whether a significant amount of the variance in clutch size is accounted for by consideration of age and size at maturity.

Simple regression analyses of mean clutch size on snout-vent length at maturity were computed for the subsamples mentioned above (Fig. 1). The regressions for single vs. multiple-brooded and oviparous versus viviparous species were compared by covariance analyses.

All of the above was concerned strictly with the interspecific comparisons. For intraspecific comparison of the body sizeclutch size relationship, we chose $U$ ta stansburiana, a species for which samples were available from many populations through much of the range of the species. Most of these samples were collected from May 8 to June 4, 1967. In each sample the clutch size was determined from counts of oviducal eggs or of yolked ovarian follicles. Tinkle $(1961,1967)$ has shown that the differences in clutch size estimated by these two methods are not significant.

Covariance analysis was used to compare the regressions of clutch size on snout-vent length for each population. The regressions were linear and the variances homogeneous for the lizard data. Tilley (1968), making similar comparisons between salamanders found that these conditions were not met, requiring transformation of the data.

The statistical terminology follows that of Steel and Torrie (1960) and Snedecor (1966). 

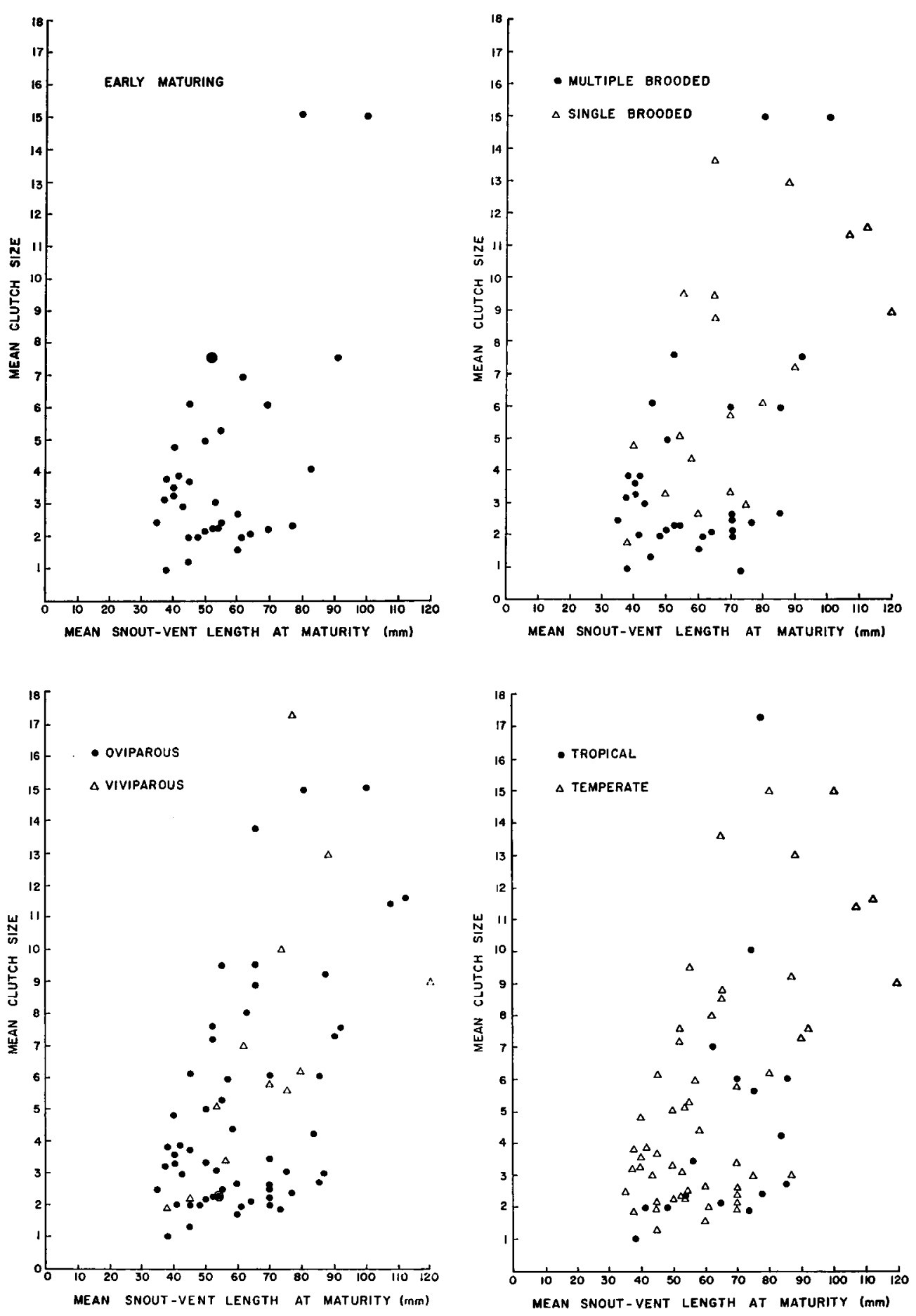

Fig. 1. Regression of clutch size on body size for several different groups of lizards based upon their reproductive habits or climatic zone inhabited. 
TABLE 2. Two way variable comparisons for all available data on lizard species. $[*, * *, * * *-.05, .01, .001$ probability levels.]

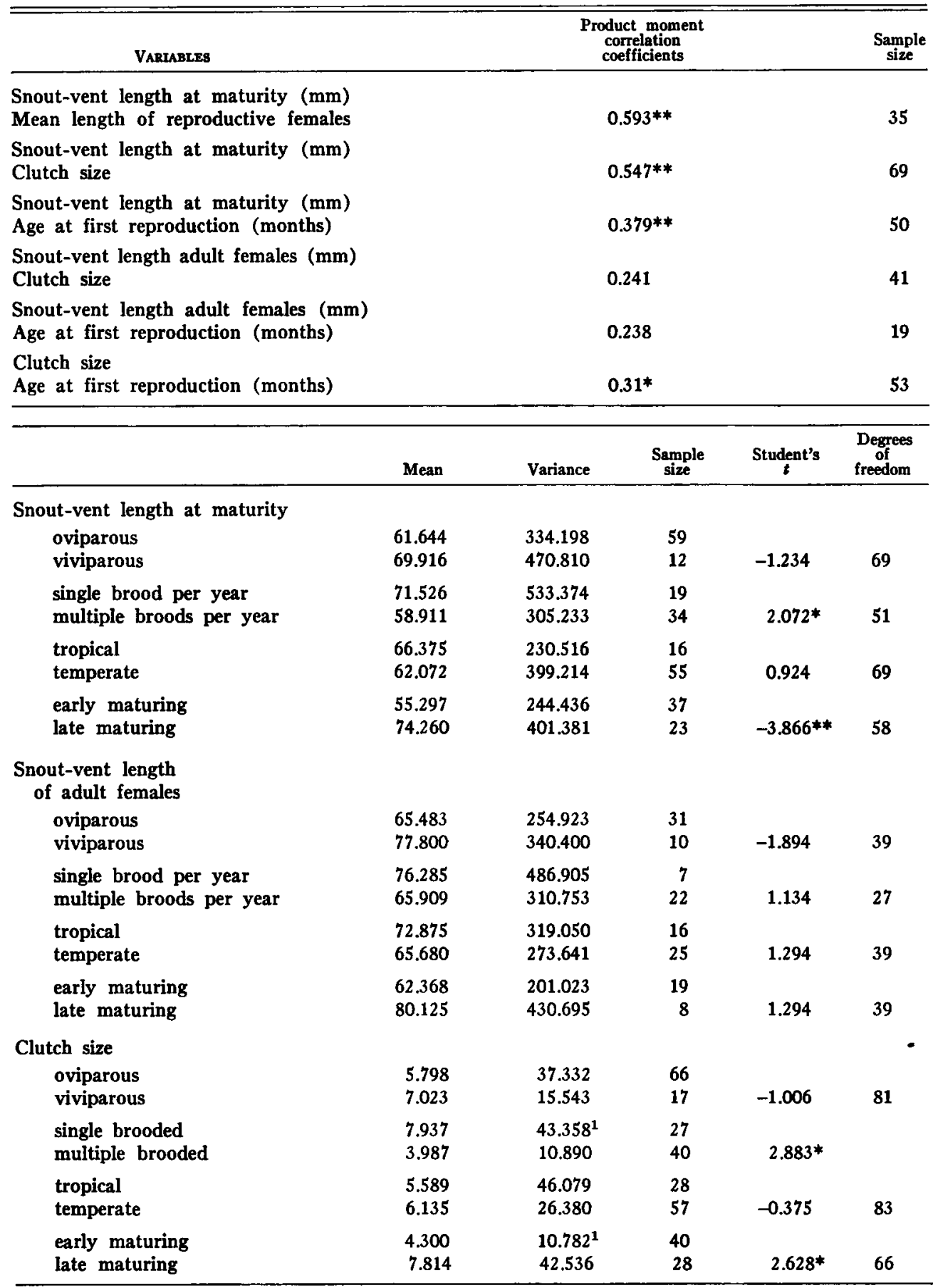

${ }^{1}$ Sample had unequal variances; means were compared by adjusted student's $t$ (Cochran and Cox, 1957). 
TABLE 2. (Continued)

\begin{tabular}{|c|c|c|c|}
\hline & Contingency Table & Probability & \\
\hline & oviparous & viviparous & \\
\hline Single brooded & 16 & 9 & $P^{* * *} \quad$ (more extreme $<.001$ \\
\hline \multirow[t]{2}{*}{ Multiple brooded } & 41 & 1 & distribution) \\
\hline & oviparous & viviparous & \\
\hline Tropical & 21 & 7 & $X^{2}=0.60$ \\
\hline \multirow[t]{2}{*}{ Temperate } & 51 & 9 & \\
\hline & oviparous & viviparous & \\
\hline \multirow{3}{*}{$\begin{array}{l}\text { Early maturing } \\
\text { Late maturing }\end{array}$} & 42 & 1 & $P^{* * *} \quad$ (more extreme $=0.001$ \\
\hline & 18 & 8 & distribution) \\
\hline & tropical & temperate & \\
\hline \multirow{3}{*}{$\begin{array}{l}\text { Single brooded } \\
\text { Multiple brooded }\end{array}$} & 3 & 23 & $P^{* * *} \quad$ (more extreme $<0.001$ \\
\hline & 15 & 22 & distribution) \\
\hline & tropical & temperate & \\
\hline \multirow{3}{*}{$\begin{array}{l}\text { Early maturing } \\
\text { Late maturing }\end{array}$} & 12 & 31 & $P \quad($ more extreme $=0.09$ \\
\hline & 3 & 23 & distribution) \\
\hline & $\begin{array}{c}\text { early } \\
\text { maturing }\end{array}$ & $\begin{array}{c}\text { late } \\
\text { maturing }\end{array}$ & \\
\hline Single brooded & 2 & 21 & $P^{* * *} \quad$ (more extreme $<0.001$ \\
\hline Multiple brooded & 32 & 2 & distribution) \\
\hline
\end{tabular}

\section{Results}

\section{Correlates of Clutch Size}

There is a highly significant positive correlation $(r=0.547 ; P<.01)$ between snout-vent length at maturity and mean clutch size (Table 2). There is also a significant correlation $(r=0.31 ; .05>$ $P>.01)$ between clutch size and age at first reproduction; this is also shown by the significantly different clutch sizes of the groups of early and late maturing lizards $(t=2.628 ; .05>P>.01)$.
Approximately $26 \%$ of the variance in clutch size among all species is accounted for by consideration of differences between these species in size and age at maturity. Size at maturity accounts for a significant amount of the variance in clutch size; an insignificant additional reduction of variance is gained from consideration of age at maturity $(F=0.165)$. In addition, there are some interesting correlations between clutch size and some other parameters. Mean clutch sizes and the mean body sizes do not differ significantly either

TABLE 3. Results of regression analyses of mean clutch size on snout-vent length at maturity for various groups of lizards.

$[*, * *-.05, .01$ probability levels. $]$

\begin{tabular}{|c|c|c|c|c|c|c|}
\hline Grouping & $N$ & $\begin{array}{c}\text { Mean } \\
\text { body } \\
\text { size } \\
(\mathrm{mm})\end{array}$ & $\begin{array}{c}\text { Mean } \\
\text { clutch } \\
\text { size }\end{array}$ & $\boldsymbol{b}$ & $a$ & $r$ \\
\hline Single-brooded & 19 & 71.68 & 7.07 & .090 & .619 & $.558 *$ \\
\hline Multiple-brooded & 32 & 58.69 & 3.96 & .092 & -1.440 & $.489 * *$ \\
\hline Oviparous & 57 & 61.84 & 4.85 & .097 & -1.148 & $.512 * *$ \\
\hline Viviparous & 12 & 69.92 & 7.21 & .124 & -1.460 & $.595^{*}$ \\
\hline Early-maturing & 35 & 55.26 & 4.27 & .114 & -2.030 & $.563^{* *}$ \\
\hline Late-maturing & 22 & 72.55 & 6.48 & & & .379 \\
\hline Temperate & 53 & 62.30 & 5.42 & .109 & -1.371 & $.602 * *$ \\
\hline Tropical & 16 & 66.38 & 4.74 & & & .409 \\
\hline
\end{tabular}


between oviparous and viviparous or between tropical and temperate species. There is a significant $(t=2.883 ; .05>$ $P>$.01) difference, almost two-fold, between the large mean clutch size of singlebrooded and the small mean clutch size of multiple-brooded species. Single-brooded lizards have a larger mean body size than multiple-brooded species $(t=2.072 ; .05$ $>P>.01$ ) .

Simple regressions of mean clutch size on size at maturity (Fig. 1; Table 3) were appropriate because consideration of age at maturity contributed insignificantly to the variance around the regression. Furthermore, the sample sizes were increased by allowing us to use species for which age at maturity was not known.

Body size and clutch size are not significantly correlated in late-maturing or in tropical species (Table 3), a fact suggested by the multiple correlations discussed previously. The sample sizes in these two groups are larger than those for viviparous and for single-brooded species within which significant correlations were found.

Covariance analysis of the two comparisons in which clutch size and body size were significantly correlated (Table 4) indicate that data for oviparous and viviparous species lie on the same regression line. The points for single-brooded lizards lie on a regression line with the same slope as that for multiple-brooded species, but with a higher elevation. Therefore, singlebrooded lizards at any given body size lay larger clutches than multiple-brooded lizards.

\section{Intraspecific Comparisons}

Differences in clutch size between species must arise through selection acting on variations in clutch size among individuals within populations of a species. In other words, it is the difference in selective regimes within species populations that ultimately produces differences between species. It is necessary to demonstrate that clutch sizes do indeed vary within and between populations of the
TABLE 4. Results of covariance analyses comparing mean clutch size to mean snout-vent length at maturity regressions for various groupings of lizards.

A) Single versus multiple-brooded species.

\begin{tabular}{lccr}
\hline $\begin{array}{l}\text { Source of } \\
\text { variance }\end{array}$ & $D . F$. & $b$ & $\begin{array}{c}\text { Mean } \\
\text { square }\end{array}$ \\
\hline Within & 47 & & 9.308 \\
$\begin{array}{l}\text { Regression } \\
\text { coefficient }\end{array}$ & 1 & & .022 \\
Common & 48 & .091 & 9.115 \\
Adjusted means & 1 & & 40.556 \\
Total & 49 & .104 & 9.756 \\
$\quad F_{\text {slope }}=.002, P>.05$ \\
$\quad F_{\text {slev }}=4.450, .05>P>.01$ \\
\hline
\end{tabular}

B) Oviparous versus viviparous species.

\begin{tabular}{lccr}
\hline $\begin{array}{l}\text { Source of } \\
\text { variance }\end{array}$ & $D . F$. & $b$ & $\begin{array}{r}\text { Mean } \\
\text { square }\end{array}$ \\
\hline Within & 65 & & 10.028 \\
$\begin{array}{l}\text { Regression } \\
\text { coefficient }\end{array}$ & 1 & & \\
$\begin{array}{l}\text { Common } \\
\text { Adjusted means }\end{array}$ & 66 & .102 & 3.043 \\
Total & 1 & & 9.922 \\
$\quad 67$ & .107 & 10.112 \\
$\quad F_{\text {sl ope }}=.303, P>.05$ & \\
$\quad F_{\text {elev }}=2.277, P>.05$ & \\
\hline
\end{tabular}

same species, and further, that such differences can be inferred to have selective advantage in one or more populations. Tinkle (1967) has cited the numerous instances in which authors have noted increased clutch sizes in larger or older individuals within populations, and has demonstrated that differences in clutch size between at least two widely separated geographic populations of the lizard Uta stansburiana can be related to differences in the relative advantage of small body size versus large body size in these two populations (Tinkle, 1969b).

Table 5 summarizes the intrapopulation regressions of clutch size on snout-vent length for 23 populations of Uta stansburiana. The various populations differ considerably from one another in the degree to which these two variables are correlated. Geographic variation in the 
TABLE 5. Summaries of regression analyses of clutch size versus body size for populations of Uta stansburiana.

$[*, * *-.05, .01$ probability levels.]

\begin{tabular}{|c|c|c|c|c|c|c|c|c|}
\hline Date & & Locality & $N$ & $\begin{array}{l}\text { Mean } \\
\text { body } \\
\text { size } \\
\text { (mm) }\end{array}$ & $\begin{array}{l}\text { Mean } \\
\text { clutch } \\
\text { size }\end{array}$ & $b$ & $a$ & $r$ \\
\hline \multicolumn{9}{|l|}{ Spring-summer } \\
\hline \multicolumn{9}{|l|}{ Spring-summer } \\
\hline $1959-60$ & $"$ & Armstrong Co. & 24 & 44.042 & 4.000 & & & .300 \\
\hline \multicolumn{9}{|l|}{ Spring-summer } \\
\hline $1959-60$ & $"$ & Ward Co. & 52 & 45.865 & 3.500 & & & .225 \\
\hline \multirow{2}{*}{$\begin{array}{l}7 \text { Jun } 1963 \\
\text { Jun-July } 1965^{1}\end{array}$} & Colo: & $\begin{array}{c}\text { Kermit } \\
\text { Colo. Nat. }\end{array}$ & 20 & 48.850 & 4.400 & & & .283 \\
\hline & Mor & nument & 135 & 42.822 & 3.200 & .106 & -1.339 & $.428^{* *}$ \\
\hline 19 May $1968^{1}$ & Ariz: & Page & 25 & 46.600 & 3.400 & .147 & -3.450 & $.470^{*}$ \\
\hline 8-9 May $1967^{1}$ & Calif: & Victorville & 27 & 43.815 & 3.037 & .168 & -4.324 & $.464 *$ \\
\hline 15-16 May 1967 & $"$ & Lone Pine & 19 & 43.737 & 3.105 & & & .049 \\
\hline 16 May $1967^{1}$ & $"$ & $5.4 \mathrm{mi} \mathrm{N}$ Bishop & 24 & 45.750 & 3.875 & .234 & -6.831 & $.585 * *$ \\
\hline 11 May 1968 & $"$ & $5.4 \mathrm{mi} \mathrm{S}$ Bishop & 23 & 46.000 & 2.565 & & & .203 \\
\hline \multicolumn{9}{|l|}{31 March- } \\
\hline $1 \mathrm{Apr} 1962$ & $"$ & Riverside Co. & 17 & 45.000 & 3.588 & & & .291 \\
\hline 7-8 May 1968 & " & Shoshone & 14 & 46.857 & 3.714 & & & .026 \\
\hline 24 May $1967^{1}$ & Nev: & Wendover & 20 & 43.550 & 3.700 & .168 & -3.616 & $.619 * *$ \\
\hline 19 May $1967^{1}$ & 11. & Ely & 16 & 46.750 & 4.750 & .176 & -3.478 & $.858^{* *}$ \\
\hline 21 May $1967^{1}$ & " 1 & Eastgate & 23 & 46.043 & 4.130 & .224 & -6.184 & $.789 * *$ \\
\hline 22-23 May $1967^{1}$ & 111 & Pyramid Lake & 26 & 45.423 & 4.077 & .191 & -4.599 & $.680 * *$ \\
\hline 15 May 1967 & $"$ & Daylight Pass & 21 & 45.286 & 4.333 & .326 & -10.430 & $.576 * *$ \\
\hline 17 May $1967^{2}$ & & Tonopah & 21 & 45.762 & 4.476 & .200 & -4.676 & $.558^{* *}$ \\
\hline 18 May 1967 & Nev: & Caliente & 16 & 45.438 & 4.000 & & & .250 \\
\hline \multicolumn{9}{|l|}{29 May- } \\
\hline 1 June $1967^{1}$ & Utah: & Grantsville & 31 & 46.194 & 4.387 & .288 & -8.917 & $.713 * *$ \\
\hline 26-27 May 1967 & $"$ & Hurricane & 19 & 46.053 & 4.105 & & & .426 \\
\hline 28 May 1967 & $"$ & Delta & 21 & 46.095 & 3.619 & & & .125 \\
\hline 27 May $1967^{1}$ & $"$ & Leeds & 21 & 46.095 & 4.000 & .245 & -7.293 & $.670 * *$ \\
\hline 26 May $1967^{1}$ & $"$ & Santa Clara & 21 & 46.095 & 3.571 & .127 & -2.283 & $.439 *$ \\
\hline
\end{tabular}

${ }^{1}$ Populations included in covariance analyses.

correlation between body size and clutch size indicates a cline from relatively high correlation in the north to relatively low correlation in the southwest (Table 5). In central Nevada, large body size is closely correlated with a large clutch, but in southern Nevada (Daylight Pass, Tonapah, Caliente), southwestern Utah (Delta, Leeds), and southern California body sizes are large but not accompanied by proportionately large clutches.

Even among those populations showing significant correlation of clutch size with body size there are differences in the variances around the regression lines (Table 5). These residual variances are unrelated to mean body sizes of the populations, making transformation of the data inappropriate. Thus, not all populations could be included in the covariance analysis, which assumes homogeneous variance around the regression being tested. The populations that were included are indicated in Table 5, the results of the covariance analyses in Table 6 .

The $F$-test of the variance introduced by fitting a common slope to the data was significant $\left(F_{\text {slope }}=1.927 ; .05>P>.01\right)$ indicating that not all of the regressions of body size on clutch size have the same slope. The Colorado population was excluded and the covariance analysis re- 
TABLE 6. Results of covariance analyses comparing clutch size-body size regressions for Uta stansburiana populations. (A) Comparison of all populations for which $\mathrm{r}$ is significant at the $95 \%$ level. (B) Comparison of the above populations A)

\begin{tabular}{lccc}
\hline \hline $\begin{array}{l}\text { Source of } \\
\text { variance }\end{array}$ & D.F. & $b$ & $\begin{array}{r}\text { Mean } \\
\text { square }\end{array}$ \\
\hline Within & 366 & & .365 \\
$\begin{array}{l}\text { Regression } \\
\text { coefficient }\end{array}$ & 11 & & .703 \\
Common & 377 & .170 & .375 \\
\multicolumn{1}{c}{$F_{\text {alope }}=1.927, .05>P>.01$} & \\
\hline
\end{tabular}

B)

\begin{tabular}{lccc}
\hline $\begin{array}{l}\text { Source of } \\
\text { variance }\end{array}$ & $D . F$. & $b$ & $\begin{array}{c}\text { Mean } \\
\text { square }\end{array}$ \\
\hline Within & 233 & & .399 \\
$\begin{array}{l}\text { Regression } \\
\text { coefficient }\end{array}$ & 10 & & .294 \\
Common & 243 & .198 & .395 \\
Adjusted means & 10 & & 4.204 \\
Total & 253 & .545 \\
$\quad F_{\text {slope }}=.737, P>.05$ & \\
$\quad F_{\text {elov }}=10.650, P<.01$ & \\
\hline
\end{tabular}

peated. The slopes of the remaining populations did not differ significantly. If the sample sizes from populations other than Colorado had been as large as that for Colorado, other slope differences might have been detectable.

The absence of slope differences among the remaining populations made it possible to test for differences in the elevations of the regression lines which are significant between populations $\left(F_{\text {elev }}=10.650\right.$; $P<.01)$. The Y-intercepts for different geographic samples suggest a gradient from higher intercepts in the north to lower ones in the south (Table 5).

The regression of clutch size on body size for all Uta stansburiana populations was compared with that for all oviparous, multiple-brooded species of lizards. This group was chosen for comparison because utas are oviparous and multiple-brooded. The results of these analyses are compared
TABLE 7. Comparison of simple regression analysis of clutch size on body size for all oviparous multiple-brooded species and 24 populations of Uta stansburiana.

$[*, * *-.05, .01$ probability levels.]

\begin{tabular}{llc}
\hline & $\begin{array}{c}\text { Oviparous- } \\
\text { multiple } \\
\text { brooded } \\
\text { species }\end{array}$ & $\begin{array}{c}\text { Uta } \\
\text { stansburiana } \\
\text { populations }\end{array}$ \\
\hline Sample size & 32 & 24 \\
Mean body size & 58.688 & 45.580 \\
Mean clutch size & 3.959 & 3.816 \\
Correlation coefficient & $0.489^{* *}$ & $0.443^{*}$ \\
Regression slope & 0.092 & 0.179 \\
y-intercept & -1.418 & -4.343 \\
Variance analysis & & \\
$\quad$ Total mean square & 11.376 & 0.267 \\
$\quad$ Regression & & \\
$\quad$ mean square & 84.233 & 1.212 \\
$\quad$ Error mean square & 8.947 & 0.224 \\
$\quad F$ regression/error & 9.414 & $5.410^{*}$ \\
\hline
\end{tabular}

in Table 7. Size and fecundity are significantly correlated within the multiplebrooded species and within Uta stansburiana. The residual variance is higher for the interspecific regression $\mathbf{( 8 . 9 4 7}$ versus 0.224$)$, indicating that the higher significance level is due to a greater spread of snout-vent lengths rather than to a tighter clustering of points around the regression line. This heterogeneity of the residual variances precludes comparison of the regression lines by covariance analysis; the two slope estimates $(.092 \pm .182$ for the multiple-brooded oviparous species and $.179 \pm .159$ for Uta stansburiana) do not differ significantly $(P>.05)$.

\section{The Identification of Reproductive Strategies}

Lizards are clearly divided into two strategies: early-maturing, multiple-brooded vs. late-maturing, single-brooded (Fig. 2). Viviparity is just one form of the latter strategy inasmuch as almost all viviparous species produce one litter per year and have a significantly $(t=5.585 ; P<.001)$ later age at first reproduction. As can be 


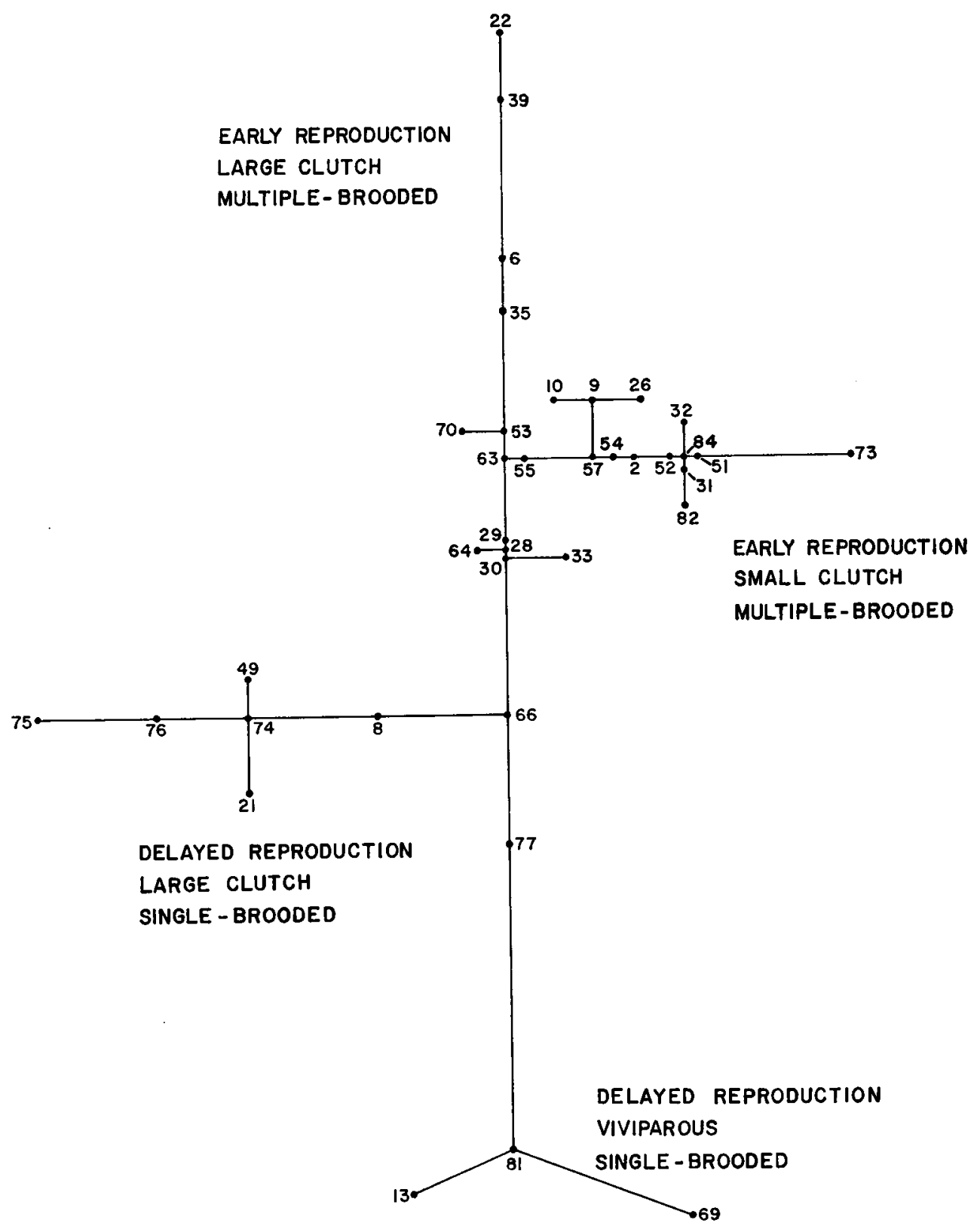

FIG. 2. Prim network of 37 species of lizards based upon reproductive strategies. Numerals refer to the number of species in Table 1.

seen from the Prim network (Fig. 2), these strategies cut across taxonomic lines.

We can state that in the early-maturing group as opposed to the late-maturing group: (1) oviparity is almost the uni- versal type of reproduction (Table 2); (2) they are nearly all multiple-brooded; (3) the mean clutch size is significantly smaller $(t=2.628 ; P<.01)$; (4) more of the variance ( $41 \%$ versus $27 \%$ ) in clutch 
size between species is accounted for by consideration of size and of age at first breeding; (5) they are smaller-bodied at maturity $(t=3.866 ; P<.01$ ) (Table 2$)$; (6) they tend to be tropical and temperate in distribution as opposed to primarily temperate for the single-brooded, delayed maturity group.

\section{Discussion}

The distinct strategies which we have deduced imply that each strategy is a coevolved complex of adaptations in morphology and ecology, as well as in reproductive physiology. Lizards which mature early have shorter adult life expectancies (Tinkle, 1969a), are almost always multiple-brooded and produce relatively small clutches. Lizards with delayed maturity must have greater survivorship, and are usually single-brooded and have larger clutches.

Because late-maturing lizards have lower per-season fecundities than early-maturing ones, it follows that in the evolution of a late-maturing species from an earlymaturing one there must have been compensations for the loss of fecundity. One of these compensations is a greater body size at first breeding which allows for a larger clutch than would be possible in a smaller-bodied lizard. It may be true that species with delayed maturity are producing larger eggs than early-maturing ones, although our data do not support this (Fig. 1); in fact, we predict that this is the case and that this type of parental care results in greater survivorship among the young from these large eggs. The virtual restriction of postdepositional parental care and viviparity to late-maturing species indicates that these particular aspects of the strategy of this group also contribute to greater egg and juvenile survivorship.

The relatively larger body sizes of adults of late-maturing species may remove them from some predation, thereby increasing their adult longevity. The re- duced intensity of their reproductive effort also may feed back positively on their adult life expectancy, ultimately providing more opportunities for reproduction.

Delayed maturity appears to be more frequent in temperate than in tropical environments. By temperate we will not necessarily restrict ourselves to a latitudinal connotation. Perhaps we should substitute "equable" for tropical and "seasonal" for temperate. The tropical lizards are a subset of the strategy of earlymaturity. The major difference between this subset and the rest of the group is the absence of a significant correlation between clutch size and size at maturity compared to a highly significant $(r=$ $0.602 ; P<.01)$ one in temperate lizards (Table 3). This must imply that clutch size in tropical species is adjusted in different ways than in temperate ones. The more intense intraspecific competition that results in tropical populations that are presumed always to be near the carrying capacity of their environment may produce selection for improved survivorship rather than for large clutches. If this is the case, then we would expect egg sizes to be larger in tropical species and clutch sizes to be smaller than in other earlymaturing species, as our data suggest. An alternate suggestion for explaining small clutch sizes in tropical species was advanced by Inger and Greenberg (1966) who argued that the competition for food precluded much fat storage, storage which has been shown to be important for reproduction in at least one temperate species (Hahn and Tinkle, 1964). The lack of a stored fat reserve reduces the number of eggs that could be produced. However, if further research demonstrates that tropical species are producing much larger, but fewer eggs, then the explanation must be sought in selection rather than in physiological limitations.

The intraspecific data on body sizeclutch size relationships of utas indicates the variability to be expected within a 
single wide-ranging species. The regressions for various populations of Uta differ primarily in elevation. This indicates that the number of eggs added to a clutch for each increment of body size varies little from population to population, a constancy previously noted by Tilley (1968) for salamanders of the genus Desmognathus. A more thorough study of these regressions within species might reveal differences in slopes, provided large samples are examined.

The apparent decrease in the Y-intercepts with latitude (Table 5) may result from the fact that late season clutches in Uta stansburiana are generally smaller than early season ones (Tinkle, 1967; Hoddenbach and Turner, 1968). Because almost all of the samples we used were collected in early summer, those lizards from the southwestern populations may have been at a later stage in their reproductive season than northern lizards. Greater variances in clutch size in late season clutches in southwestern populations may be responsible for the lower correlation of clutch size with body size. Future workers are advised to consider seasonal variation and differences in egg size when investigating latitudinal trends in clutch size.

The regression of body size and clutch size in Uta stansburiana is difficult to compare with that of the multiple-brooded lizards because the variances around the two regressions are not homogeneous (Table 7). The slopes of the regression lines are the same. In addition to sampling error, the greater residual variance about the regression line for interspecific comparisons may reflect differential evolutionary adjustment between species of clutch size independent of body size. That such adjustments have occurred seems likely from our discussion of clutch size in tropical lizards. Larger lizards apparently do not lay clutches containing either more or fewer eggs than would be predicted from the intraspecific regression shown for $U t a$ stansburiana. Evidently, within lizards of a given strategy there is a fundamental relationship between body size and clutch size that has been subject to little evolutionary adjustment.

More detailed intraspecific studies of reproductive parameters are necessary to understand selective processes within species populations and to strengthen any hypotheses about the origin of reproductive strategies.

\section{A Comparison With Birds}

Lack (1966, 1968) has reviewed the reproductive adaptations of birds. The reproductive strategies are similar in a general way to those of lizards; differences between the classes arise from the great diversity in birds of specializations such as hole-nesting, colony formation, brood parasitism and cooperative rearing of the young. The abundance of life history information and of experimental studies of bird reproduction makes the selective bases for the observed adaptations clearer than for lizards.

In birds there is no apparent intraspecific correlation between body size and clutch size; this is due in part to their determinate growth. Some iteroparous species of birds such as gulls produce smaller broods in their first year of breeding. There is likewise no correlation between clutch size and body size between species; clutches of one or two eggs are characteristic of small swifts and hummingbirds, but also of the large raptors and albatrosses. Large clutches are observed in small tits as well as some large ducks. Clutch sizes in birds are positively correlated with high latitudes, hole-nesting, nidifugous young, early, maturity and with savannah as opposed to forest habitats.

Birds, like the lizards, may be divided into two groups on the basis of their age at first reproduction. Early-maturing birds (most nidicolous land birds and the nidifugous aquatic birds) generally 
lay large clutches (in contrast to lizards), have short developmental periods and a low annual survivorship. Their nesting sites are relatively accessible to predators. The rapid developmental period from laying to fledging permits replacement of lost broods and, in many species, allows two or more reproductions per season. The larger clutch sizes of early-maturing birds compared to lizards is probably attributable to parental care of the young in birds.

The second group of birds (including large raptors, swifts and some colonial sea birds) is characterized by delayed reproduction, small clutches, single broods per season, high annual adult survivorship and long developmental periods. These birds nest in sites inaccessible to most predators so that the long incubation and fledging periods are not a great risk. This prolonged developmental period is considered an adaptation to the irregular feeding schedule imposed by an unpredictable food supply. The delayed maturity is thought to be imposed by the necessity of a period of learning by a young bird; premature reproduction is a risk to future reproductive success and hence is selected against.

Whatever environmental circumstances are responsible for the evolution of delayed maturity in birds and in lizards, in neither group is there evidence that delayed maturity is due simply to physiological inability to mature in a shorter period of time. Stable populations can result only when delayed maturity is accompanied by adjustment of other life history parameters such as degree of parental care, adult life expectancy, clutch size and the frequency of clutches (Cole, 1954). Latematuring lizards have three adaptations to counter the cost in fitness imposed by delayed maturity. One adaptation is the production of larger clutches, achieved in part by growth to a larger size before maturity. The other is by increasing parental care and viviparity. The last is a longer reproductive life expectancy. Although birds have not evolved viviparity, the large raptors and sea birds have increased the period of parental care for their one or two chicks to the point that the high probability of the young surviving to maturity coupled with a long breeding life expectancy of the adult balances the reproductive cost of delayed maturity.

\section{Suggestions for Future Study}

Data on tropical species, particularly those in constant environments, are badly needed as are more intraspecific population studies. Critical items of information needed are exact ages at first breeding, number of clutches actually produced in a single season, absolute size of eggs, egg size relative to weight of female, the reproductive life expectancy of adults, their age-specific fecundities and mortalities, and the survivorship of hatchling animals to sexual maturity. These items have been neglected in part because their significance has not been generally appreciated and in part because these are the items most difficult to study. As Turner (1968) has pointed out in review of Tinkle (1967), some items of information collected in life history studies constitute field bookkeeping and often are not collected with the view of answering particular questions. It is our judgment that the amount of time invested in any life history study could be better spent if concentrated on answering some specific questions.

\section{ACKNOWLEDGMENTS}

This research was supported in part by grants from the National Science Foundation (GB 4396; GB 8706; GB 5416x) to Tinkle and by a NSF Grant for Systematic and Evolutionary Biology (GB 8212, Nelson Hairston, Principal Investigator) to Stephen G. Tilley. Henry Wilbur was supported by a NSF predoctoral fellowship. We are grateful to Charles $O$. McKinney of the University of Michigan for furnishing the samples of Uta stansburiana for the intraspecific analyses. 


\section{Literature Cited}

Alcala, A. C., and W. C. Brown. 1967. Population ecology of the tropical scincoid lizard, Emoia atrocostata, in the Philippines. Copeia 1967 (3) :596-604.

Asana, J. J. 1931. The natural history of Calotes versicolor (Boulenger), the common blood-sucker. J. Bombay Natur. Hist. Soc. 34:1041-1047.

Baker, J. R. 1947. The seasons in a tropical rain-forest. Part 6. Lizards (Emoia). J. Linn. Soc. London 41:243-247.

Barwick, R. E. 1959. The life history of the common New Zealand skink Leiolopisma zelandica (Gray, 1843). Trans. Roy. Soc. New Zealand 86(3-4):331-380.

BlaIR, W. F. 1960. The rusty lizard. A population study. Univ. Texas Press, Austin.

Bostic, D. L. 1966. A preliminary report of reproduction in the teiid lizard, Cnemidophorus hyperythrus beldingi. Herpetologica 22 (2) :81-90.

Breckenringe, W. J. 1943. The life history of the black-banded skink Eumeces septentrionalis septentrionalis (Baird). Amer. Midl. Natur. 29 (3):591-606.

Brooks, G. R., JR. 1967. Population ecology of the ground skink, Lygosoma laterale (Say). Ecol. Monogr. 37(2):72-87.

Bustard, H. R. 1965. Observations on the life history and behavior of Chamaeleo hohnelii (Steindachner). Copeia 1965(4):401-410.

- 1966. Observations on the life history and behavior of Chameleo bitaeniatus Fischer. Herpetologica 22(1):13-23.

CAgLe, F. R. 1950. Notes on Holbrookia texana in Texas. Copeia 1950(3):230.

Carpenter, C. C. 1959. A population of the six-lined racerunner (Cnemidophorus sexlineatus). Herpetologica 15(2):81-86.

- 1960a. Parturition and behavior at birth of Yarrow's spiny lizard (Sceloporus jarrovi). Herpetologica 16(2):137-138.

- 1960b. Reproduction in Oklahoma Sceloporus and Cnemidophorus. Herpetologica 16 (3) : 175-182.

- 1966. The marine iguana of the Galapagos Islands, its behavior and ecology. Proc. California Acad. Sci. 34(6):329-376.

Chaney, A. H., and $\boldsymbol{R}$. E. Gordon. 1954. Notes on a population of Sceloporus merriami merriami Stejneger. Texas J. Sci. 6(1):7882.

Chapman, B. M., and R. F. Chapman. 1964. Observations on the biology of the lizard Agama agama in Ghana. Proc. Zool. Soc. London 143:121-132.

CoLe, L. C. 1954. The population consequences of life history phenomena. Quart. Rev. Biol. 29:103-137.
Crenshaw, J. W, Jr. 1955. The life history of the southern spiny lizard, Sceloporus undulatus undulatus Latreille. Amer. Midl. Natur. 54:257-298.

Daniel, P. M. 1960 . Growth and cyclic behavior in the West African lizard, Agama agama africana. Copeia 1960(2):94-97.

Davis, J. 1967. Growth and size of the western fence lizard (Sceloporus occidentalis). Copeia 1967 (4) : 721-731.

FITCH, H. S. 1935. Natural history of the alligator lizards. Trans. Acad. Sci. St. Louis 29(1):1-38.

- 1940. A field study of the growth and behavior of the fence lizard. Univ. California Publ. Zool. 44(2):151-172.

- 1954. Life history and ecology of the five-lined skink, Eumeces fasciatus. Univ. Kansas Publ. Mus. Natur. Hist. 8:1-156.

-1955. Habits and adaptations of the Great Plains Skink (Eumeces obsoletus). Ecol. Monogr. 25:59-83.

- 1956. An ecological study of the collared lizard (Crotaphytus collaris). Univ. Kansas Publ. Mus. Natur. Hist. 8(3):213-274.

- 1958. Natural history of the six-lined racerunner (Cnemidophorus sexlineatus). Univ. Kansas Publ. Mus. Natur. Hist. 11(2):11-62. - 1967. Ecological studies of lizards on the University of Kansas Natural History Reservation. In: W. W. Milstead [ed.], Lizard ecology: A Symposium. Univ. Missouri Press, Kansas City.

Fitch, H. S., ANo H. W. Greene. 1965. Breeding cycle in the ground skink, Lygosoma laterale. Univ. Kansas Publ. Mus. Natur. Hist. 15(11): 565-575.

Fukada, H. 1965. Breeding habits of some Japanese reptiles (Critical Review). Bull. Kyoto Gakugei Univ., ser. B, 27:65-82.

Givler, J. P. 1922. Notes on the oecology and life-history of the Texas horned lizard, Phrynosoma cornutum. J. Elisha Mitchell Sci. Soc. 37:130-137.

Gordon, R. E. 1956. The biology and biodemography of Anolis carolinensis carolinensis Voigt. Diss. Abstr. 17:698.

Greer, A. E. 1967. Notes on the mode of reproduction in anguid lizards. Herpetologica 23(2):94-99.

Greer, A. E., ANd F. Parker. 1967. A new scincid lizard from the northern Solomon islands. Breviora 275:1-20.

Hahn, W. E., AND D. W. Tnnkle. 1964. Fat body cycling and experimental evidence for its adaptive significance to ovarian follicle development in the lizard Uta stansburiana. J. Expt. Zool. 158:79-86.

Hamlett, G. W. D. 1952. Notes on breeding 
and reproduction in the lizard Anolis carolinensis. Copeia 1952(3):183-185.

Harris, V. A. 1964. The life of the rainbow lizard. Hutchison and Co., Ltd, London.

HIRTH, H. F. 1963. The ecology of two lizards on a tropical beach. Ecol. Monogr. 33:83-112.

Hoddenbach, G. A. 1965. A comparison of reproduction in two lizards: Cnemidophorus tigris marmoratus and Uta stansburiana stejnegeri. Unpubl. M.S. Thesis, Texas Tech. Coll.

- 1966. Reproduction in western Texas Cnemidophorus sexlineatus (Sauria: Teiidae). Copeia 1966(1):110-113.

Hodpenbach, G. A., AND F. B. Turner. 1968. Clutch size of the lizard Uta stansburiana in southern Nevada. Amer. Midl. Natur. 80: 262-265.

Hunsaker, D., II. 1959. Birth and litter sizes of the blue spring lizard Sceloporus cyanogenys. Copeia 1959(3):260-261.

Inger, R. F., AND B. Greenberg. 1966. Annual reproductive patterns of lizards from a Bornean rain forest. Ecology 47(6):10071021.

IshIHARA, S. 1964. Observation on egg-laying and hatching of the lizard, Takydromus tachydromoides. Bull. Kyoto Gakugei Univ., ser. B, 25:79-85.

Johnson, C. 1960. Reproductive cycle in females of the greater earless lizard, Holbrookia texana. Copeia 1960(4):297-300.

Jornson, R. M. 1953. A contribution to the life history of the lizard Scincella laterale (Say). Tulane Stud. Zool. 1(2):11-27.

Johnson, S. R. 1965. An ecological study of the chuckwalla, Sauromalus obesus Baird, in the western Mojave desert. Amer. Midl. Natur. 73:1-29.

Kopstein, E. 1938. Ein Beitrag zur Eierkunde und zur Fortpflanzung der Malaiischen Reptilien. Bull. Raffles Museum 14:81-168.

LACK, D. 1954. The evolution of reproductive rates. In: J. S. Huxley, A. C. Hardy, E. B. Ford [eds.], Evolution as a process. Allen and Unwin, Ltd., London.

- 1966. Population studies of birds. Clarendon Press, Oxford.

- 1968. Ecological adaptations for breeding in birds. Methuen and Co., Ltd., London.

Mayhew, W. W. 1963a. Reproduction in the granite spiny lizard, Sceloporus orcutti. Copeia 1963(1): 144-152.

- 1963b. Biology of the granite spiny lizard, Sceloporus orcutti. Amer. Midl. Natur. 69(2): 310-327.

-1965. Reproduction in the sand-dwelling lizard Uma inornata. Herpetologica 21(1): $39-55$.

-. 1966a. Reproduction in the psammophi- lous lizard Uma scoparia. Copeia 1966(1): 114-122.

- 1966b. Reproduction in the arenicolous lizard Uma notata. Ecology 47(1):9-18.

McCann, C. 1940. A reptile and amphibian miscellany. J. Bombay Natur. Hist. Soc. 42: 45-65.

McCauley, R. H. 1945. The reptiles of Maryland and the District of Columbia. Free Press Printing Co., Burlington, Vermont.

McCoy, C. J. 1967. Natural history notes on Crotaphytus wislizeni (Reptilia: Iguanidae) in Colorado. Amer. Midl. Natur. 77:138-146.

- 1968. Reproductive cycles and viviparity in Guatemalan Corythophanes percarinatus (Reptilia: Iguanidae). Herpetologica 24(2): 175-178.

$\longrightarrow$ AND G. A. Hoddenbach. 1966. Geographic variation in ovarian cycles and clutch size in Cnemidophorus tigris (Teiidae). Science 154: 1671-1672.

MedicA, P. A. 1967. Food habits, habitat preference, reproduction, and diurnal activity in four sympatric species of whiptail lizards (Cnemidophorus) in south central New Mexico. Bull. So. California Acad. Sci. 66:251276.

MrLler, M. R. 1951. Some aspects of the life history of the yucca night lizard, Xantusia vigilis. Copeia 1951(2):114-120.

- 1954. Further observations on reproduction in the lizard Xantusia vigilis. Copeia 1954(1):38-40.

Montanucct, R. R. 1965. Observations on the San Joaquin Leopard Lizard, Crotaphytus wislizeni silus Stejneger. Herpetologica 21(4): 270-283.

- 1967. Further studies on leopard lizards, Crotaphytus wislizeni. Herpetologica 23(2): 119-126.

Mount, R. H. 1963. The natural history of the red-tailed skink, Eumeces egregius Baird. Amer. Midl. Natur. 70(2):356-385.

Murphy, G. 1968. Pattern in life history and the environment. Amer. Natur. 102:391-404.

Pearson, O. P. 1954. Habits of the lizard Liolaemus multiformis multiformis at high altitudes in southern Peru. Copeia 1954(2): 111-116.

PrIM, R. C. 1957. Shortest connection networks and some generalizations. Bell Syst. Tech. J. 36(6):1389-1401.

RAND, A. S. 1968. A nesting aggregation of iguanas. Copeia 1968(3):552-561.

Robertson, I. A. D., B. M. Chapman, and R. F. Chapman. 1965. Notes on the biology of the lizards Agama cyanogaster and Mabuya striata striata collected in the Rukwa Valley, southwest Tanganyika. Proc. Zool. Soc. London $145(2): 305-320$. 
RODGers, T. L., AND V. H. MemMter. 1943. Growth in the western blue-tailed skink. Trans. San Diego Soc. Natur. Hist. 10(3): 63-67.

Rollnat, R. 1934. La Vie des Reptiles de la France Centrale. Librairie Delagrave, Paris.

Rustamov, A. K., AND S. Shammakov. 1967. Ecology of Phrynocephalus helioscopus helioscopus in Turkmenia. Zool. Zhur. 46:741748.

Sexton, O. J., H. F. Heatwole, and E. H. Meseth. 1963. Seasonal population changes in the lizard, Anolis limifrons, in Panama. Amer. Midl. Natur. 69(2):482-491.

SmITH, M. 1951. The British amphibians and reptiles. Collins, London.

SmrTH, R. E. 1968. Studies on reproduction in Costa Rican Ameiva festiva and Ameiva quadrilineata (Sauria: Teidae). Copeia 1968 (2):236-239.

SNEDECOR, G. W. 1966. Statistical methods. 5th ed. Iowa State Univ. Press, Ames.

Stebrins, R. C. 1944. Field notes on a lizard, the mountain swift, with special reference to territorial behavior. Ecology 29(2):233-248.

- 1948. Additional observations on home ranges and longevity in the lizard Sceloporus graciosus. Copeia 1948(1):20-22.

Stebbins, R. C., AND H. B. Robinson. 1946. Further analysis of a population of the lizard Sceloporus graciosus gracilis. Univ. California Publ. Zool. 48(3) : 149-168.

Stebins, R. C., J. M. Lowenstein, and N. W. Comen. 1967. A field study of the lava lizard (Tropidurus albemarlensis) in the Galapagos Islands. Ecology 48(5): 839-851.

Steel, R. G. D., AND J. H. TORRIE. 1960. Principles and procedures of statistics. McGraw-Hill Co., Inc., New York.

StorR, G. M. 1967. Geographic races of the agamid lizard Amphibolurus caudicinctus. J. Roy. Soc. Western Australia 50:49-56.

SvärDSON, G. 1949. Natural selection and egg number in fish. Inst. Fresh-water Research, Drottningholm. Publ. no. 29:115-122.

TANNer, W. W. 1957. A taxonomic and ecological study of the western skink (Eumeces skiltonianus). Great Basin Natur. 17(3-4): 59-94.

Telford, S. R. 1959. A study of the sand skink, Neoseps reynoldsi Stejneger. Copeia 1959(2):110-119.

- 1969. The ovarian cycle, reproductive potential, and structure in a population of the Japanese lacertid Takydromus tachydromoides. Copeia $1969(3): 548-566$.

Trley, S. G. 1968. Size-fecundity relationships and their evolutionary implications in five desmognathine salamanders. Evolution 22(4) :806-816.

TnNkee, D. W. 1961. Population structure and reproduction in the lizard Uta stansburiana stejnegeri. Amer. Midl. Natur. 66:206-234.

- 1967. The life and demography of the side-blotched lizard. Misc. Publ. Mus. Zool. Univ. Michigan 132:1-182.

- 1969a. The concept of reproductive effort and its relation to the evolution of life histories of lizards. Amer. Natur. 103:501516.

- 1969b. Evolutionary implications of comparative population studies in the lizard Uta stansburiana. In: Systematic Biology, National Academy of Sciences publ. no. 1692: 133-160.

TURner, F. B. 1968. Life history of a lizard (Review). Evolution 22(4):841-842.

Turner, F. B., P. A. Medica, and G. A. HodDenbach. Unpubl. mss. Composition and function of populations of the lizard, Cnemidophorus tigris, in southern Nevada. Unpubl. mss. sent to D. W. Tinkle for use by $F$. B. Turner, 1968.

Wriliams, G. C. 1966a. Adaptation and Natural Selection. Princeton Univ. Press, Princeton.

- 1966b. Natural selection, the costs of reproduction, and a refinement of Lack's Principle. Amer. Natur. 100:687-692.

ZweIFEL, R. G., AND C. H. Lowe. 1966. The ecology of a population of Xantusia vigilis, the desert night lizard. Amer. Mus. Novitates 2247:1-57. 